\title{
Influence of substrates on the nutritional quality of Pleurotus pulmonarius and Pleurotus ostreatus
}

\author{
T. Garuba*, K. A. Abdukkareem, I. A. Ibrahim, O. I. Oyebamiji, O. A. Shoyooye and \\ T. D. Ajibade
}

Department of Plant Biology, Faculty of Life Sciences, University of Ilorin, P.M.B. 1515, Ilorin, Nigeria

\begin{abstract}
This investigation is aimed at determining the influence of agro-wastes as substrates on the nutritional quality of Pleurotus pulmonarius and Pleurotus ostreatus. Cassava peels, banana leaves and amended sawdust (sawdust mixed with rice bran in ratio 4:1) were used as growth substrates. Proximate and mineral analyses were carried out using DA 7250 NIR Analyzer and Atomic Absorption of Spectrophotometer machine (AA320N). Both species in amended sawdust had the highest stipe length and pileus diameter of the fruiting body. Starch was the most abundant proximate constituent in the two species. The starch was the most abundant proximate constituent in the two species but highest starch contents were observed in. $P$. pulmonarius grown in cassava peels substrate and $P$. ostreatus raised in banana leaves substrate. Fat appeared to be the lowest proximate constituent in the two species. Potassium was predominant among the minerals in both $P$. pulmonarius and $P$. ostreatus and the highest value $(68.204 \mathrm{mg} / \mathrm{L})$ was observed in P. ostreatus cultivated in amended sawdust. Other minerals varied considerably and as they were differential affected by the substrates. The mushrooms contained useful nutritional constituents however their quantities were influenced by the substrates used in raising them.
\end{abstract}

Keywords: Incubation, mineral element, proximate composition, spawn running, substrates.

\section{INTRODUCTION}

The genus Pleurotus contain edible mushrooms belonging to Class Basidiomycetes and Order Agaricales. Mushrooms are widely distributed in the temperate and tropical regions (Chang and Miles, 2004). The fruit-body of the Pleurotus is oyster-shaped hence 'Oyster Mushroom' is used as the common name. Cultivation of mushroom is seen as alternative ways by which poverty in developing countries like Nigeria can be reduced due to low cost of production with high profit. P.ostratusgains ground among the mushroom farmers (Rosado et al., 2002) and this may be because it is easy to grow and economically viable. The substrates used in mushroom farming are usually agricultural remnants such as rice straw, banana leaves, sawdust, wheat straw, bamboo leaves, sugarcane tops and maize stover (Dlamini et al., 2012; Kumari and Achal, 2008).

Generally, mushrooms are very palatable and are used in the preparation of intercontinental dishes. They are very nutritious as they contain appreciable amounts of both starchy and non-starchy carbohydrates, protein including most essentialamino acids, vitamins B, $\mathrm{C}$ and E, unsaturated fatty acids and dietary fibre (Chang and Miles, 2004; Croan, 2004).Oyster mushroom contains essential minerals such as potassium, phosphorous, calcium, magnesium, sodium, iron and selenium (Ezeibekwe, 2009).

Recent pharmacological research has confirmed the medicinal efficacy of mushroom in reducing the risk of disease such as epilepsy, wounds, skin diseases, heart ailments, rheumatoid, arthritis, fever, diaphoretic, diarrhea, dysentery, cold, anesthesia, liver disease, gall bladder diseases and used as vermicides (Bahl, 1983). Also, it has antifungal, antibacterial, antitumour, anti-inflammatory, antihypertensive, antihyperglycaemic, immunomodulatory and antioxidant properties (Gregori et al,. 2007; Wani et al., 2010). Species of the genus Pleurotus are good sources of lovastatin and as such, Pleurotus could be considered as a functional food with natural cholesterol-lowering ability (Gunde-Cimerman, 1999).

One of the major plans of Nigeria government is to diversify the nation's economy. Mushroom cultivation is a promising alternative agribusiness as it has the benefits of being land 
and labour savings, requires low startup capital and is eco-friendly. Besides, the agricultural remnants and industrial wastes used as substrates are readily available. The awareness of mushroom farming has been already made but nutritional benefits from the produce needs to be identified as well. Substrates played an indispensable role in the nutritional composition of oyster mushroom and astounding imbalances have been observed in both proximate and mineral compositions of Pleurotus raised in different substrates (Bhattacharjya et al., 2015; Sarker et al., 2007).This investigation was aimed at finding out the substrates that will be most suitable for improving the fruiting bodies, proximate composition and minerals of Pleurotus pulmonarius and Pleurotus ostreatus.

\section{MATERIAL AND METHODS}

\section{Preparation of Substrates}

The substrates used were cassava peels, banana leaves and sawdust. All the substrates were soaked in water for 12 hours to moisten them thoroughly and were stalked on the steep cemented floor so as to remove the excessive moisture from the substrates (Shah et al., 2004).Amended sawdust was prepared by mixing the sawdust with rice bran in ratio 4:1. Each substrate was weighed, wetted to about $65-75 \%$ moisture content and $200 \mathrm{~g}$ of calcium carbonate $\left(\mathrm{CaCO}_{3}\right)$ was added. The squeeze method of Dlamini et al. (2012) was used to determine the moisture content. When squeezing the substrate between fingers, small amounts of water oozed from the substrate. Thereafter, $1 \mathrm{~kg}$ of each substrate was packed into an autoclaving bag and fastened using rubber bands and sterilized at 15 psi, $121{ }^{\circ} \mathrm{C}$ for $90 \mathrm{~min}$ (Kumari and Achal, 2008).

\section{Isolation and Maintenance of Pure Cultures of Desired Mushroom}

Freshly harvested P.pulmonarius and P.ostreatuswere obtained from Federal Institute of Industrial Research, Oshodi (FIIRO). Potato Dextrose Agar (PDA) was poured into petri dishes and allowed to solidify. The mushroom fruits were dissected longitudinally with a sterile razor. Small tissues from the fruits were aseptically inoculated into petri dishes containing PDA and they were incubated at $28^{\circ} \mathrm{C}$ for 7 days (Girmay et al., 2016).

\section{Spawn production}

The Sorghum bicolor grains were washed and the chaff were sorted out. It was parboiled with $\mathrm{CaCO}_{3}$ until gelatinized. After draining excess water, it was mixed with $1 \% \mathrm{CaCO}_{3}$ and gypsum $\left(\mathrm{CaSO}_{4}\right)$ to prevent adhesion of grains and for optimizing the $\mathrm{pH}$ for spawn. After cooling, it was bottled and covered with aluminum foil, thereafter autoclaved for $1 \mathrm{hr}$ at $121^{\circ} \mathrm{C}$. Pure cultures each of $P$. pulmonarius and $P$. ostreatus growing on the petri dishes were picked with a sterilized corkborer and inoculated aseptically on the grains and incubated at room temperature. The spawn was inoculated into the substrates and kept in the dark to allow the substrates to ramify.

\section{Fruiting and Harvesting}

After ramification of the substrates, the polythene bags were loosened to allow air, light and daily watering till the pin heads appeared. Matured mushrooms were harvested after about 3-4days of fruiting. Thereafter, the height of fruiting bodies, stipe length and pileus diameter were measured with calibrated ruler. The fruiting bodies were oven dried and separately packed for analyses.

\section{Proximate and Mineral analyses}

The proximate analysis of $P$. pulmonarius and $P$. ostreatus was carried out using DA 7250 NIR Analyzer. This machine incorporates Near InfraRed (NIR) technology with solid state optics and has specially designed software for its operation. The samples were pulverized prior to analysis. The samples were poured into an open dish for automatic analysis. The results were displayed on the touch-screen. FOS KJeltec ${ }^{\mathrm{TM}} 8200$ Auto Distillation Machine was used to verify the protein content in the samples. For mineral analysis, digestion and analysis was carried out using the method of Khan et al. (2011).A Flame Atomic Absorption Spectrophotometer (AA320N) was used to quantify the minerals present in the samples. Zinc (Zn), Manganese $(\mathrm{Mn})$, Iron $(\mathrm{Fe})$, Copper $(\mathrm{Cu})$, Magnessium $(\mathrm{Mg})$, Calcium (Ca), Selenium (Se) and Potassium (K) were determined. Each of the analyses was replicated three times.

\section{Data Analysis}

The data collected were analyzed using Statistical Package for Social Science (SPSS version 16.0) software. Analysis of Variance was 
carried out and the means were separated using Dunca Multiple Range Test (DMRT) at 5\% level

\section{RESULTS}

\section{Running of spawn and formation of fruiting bodies of $P$. pulmonarius and $P$. ostreatus}

Banana leaves showed the fastest rate of mycelium growth (Table 1) during the spawn running and takes about 17 days in $P$. pulmonarus and 15days in P. ostreatus for full ramification. There were significant differences in the mean number of days taken for the completion of spawn running between the substrates in the two species. Appearance of pin heads and formation of fruiting bodies were delayed most in amended sawdust substrates. of significance. Also, Origin (7.0) was used to plot the bar charts.

Effects of the substrates on the morphology of the $P$. pulmonarius and $P$. ostreatus

$P$. pulmonarius and $P$. ostreatus cultivated in amended sawdust had the highest stipe length, pileus diameter and height of fruiting body. There were no significant differences in stipe lengths of the two species grown on different substrates $(p \leq 0.05)$. Also, theamended sawdust showed a significantly higher pileus diameter, while other measurements did not show significant differences (Table 2).

Table 1: Effects of different substrates on growth and yield performance of Pleurotus pulminarius and Pleurotus ostreatus.

\begin{tabular}{llccc}
\hline $\begin{array}{c}\text { Mushroom } \\
\text { species }\end{array}$ & \multicolumn{1}{c}{ Substrates } & Spawn running & $\begin{array}{c}\text { Pin head appearance } \\
\text { Days }\end{array}$ & $\begin{array}{c}\text { Fruiting body } \\
\text { formation }\end{array}$ \\
\hline $\mathrm{Pp}$ & Banana leaves & $17.00 \pm 0.00^{\mathrm{c}}$ & $22.33 \pm 0.02^{\mathrm{c}}$ & $25.00 \pm 0.00^{\mathrm{b}}$ \\
& Cassava peels & $29.33 \pm 0.01^{\mathrm{b}}$ & $34.00 \pm 0.01^{\mathrm{b}}$ & $37.33 \pm 0.33^{\mathrm{a}}$ \\
& Amended Sawdust & $30.00 \pm 0.00^{\mathrm{a}}$ & $35.33 \pm 0.33^{\mathrm{a}}$ & $39.33 \pm 0.33^{\mathrm{a}}$ \\
$\mathrm{Po}$ & Mean & $25.44 \pm 0.00$ & $30.55 \pm 0.12$ & $33.89 \pm 0.22$ \\
& Banana leaves & $15.33 \pm 0.67^{\mathrm{a}}$ & $20.33 \pm 0.67^{\mathrm{c}}$ & $23.33 \pm 0.33^{\mathrm{c}}$ \\
& Cassava peels & $25.67 \pm 0.33^{\mathrm{b}}$ & $30.67 \pm 0.33^{\mathrm{b}}$ & $33.67 \pm 0.33^{\mathrm{b}}$ \\
& Amended Sawdust & $28.30 \pm 0.33^{\mathrm{c}}$ & $33.33 \pm 0.33^{\mathrm{a}}$ & $37.33 \pm 0.33^{\mathrm{a}}$ \\
& Mean & $23.10 \pm 0.44$ & $28.11 \pm 0.44$ & $31.44 \pm 0.33$ \\
\hline
\end{tabular}

Means followed by the same letter along the same column for each species of mushroom are not significantly different at $\mathrm{p} \leq 0.05$. $\quad \mathrm{Pp}=$ Pleurotus pulmonarius $\mathrm{Pp}=$ Pleurotus ostreatus

Table 2: Effects of substrates on the morphology of Pleurotus pulminarius and Pleurotus ostreatus.

\begin{tabular}{lcccccc}
\hline \multicolumn{2}{l}{ Pleurotus pulminarius } & \multicolumn{3}{l}{ Pleurotus ostreatus } \\
\hline Substrates & Stipe $(\mathbf{c m})$ & Pileus $(\mathbf{c m})$ & $\begin{array}{l}\text { Height of } \\
\text { fruiting bodies } \\
(\mathbf{c m})\end{array}$ & Stipe (cm) & Pileus (cm) & $\begin{array}{l}\text { Height of } \\
\text { fruiting } \\
\text { bodies (cm) }\end{array}$ \\
\hline $\begin{array}{l}\text { Banana } \\
\text { leaves }\end{array}$ & $5.33 \pm 0.33^{\mathrm{a}}$ & $4.50 \pm 0.00^{\mathrm{b}}$ & $5.73 \pm 0.33^{\mathrm{a}}$ & $5.33 \pm 0.33^{\mathrm{a}}$ & $4.50 \pm 0.00^{\mathrm{b}}$ & $5.70 \pm 0.33^{\mathrm{a}}$ \\
$\begin{array}{l}\text { Cassava } \\
\text { peels }\end{array}$ & $7.00 \pm 1.00^{\mathrm{a}}$ & $5.67 \pm 0.17^{\mathrm{ab}}$ & $7.10 \pm 0.70^{\mathrm{a}}$ & $6.00 \pm 1.00^{\mathrm{a}}$ & $4.67 \pm 0.17^{\mathrm{ab}}$ & $6.250 \pm 0.70^{\mathrm{a}}$ \\
$\begin{array}{l}\text { Amended } \\
\text { Sawdust }\end{array}$ & $8.00 \pm 1.00^{\mathrm{a}}$ & $6.33 \pm 0.33^{\mathrm{a}}$ & $8.47 \pm 0.64^{\mathrm{a}}$ & $7.00 \pm 1.00^{\mathrm{a}}$ & $5.33 \pm 0.33^{\mathrm{a}}$ & $7.46 \pm 0.64^{\mathrm{a}}$ \\
Mean & $6.78 \pm 0.78$ & $5.50 \pm 0.17$ & $7.10 \pm 0.56$ & $6.11 \pm 0.78$ & $4.83 \pm 0.17$ & $6.47 \pm 0.56$ \\
\hline
\end{tabular}

Means followed by the same letter along the same column for each substrate are not significantly different at $\mathrm{p} \leq 0.05$. 
Effects of substrates on proximate composition of $\boldsymbol{P}$. pulmonarius and $\boldsymbol{P}$. ostreatus

The percentage moisture in $P$. pulmonarius in cassava peels was the highest and significantly different from the quantity present in those harvested from banana leaves and amended sawdust. The percentage protein in $P$. pulmonarius grown in cassava peels was significantly higher than the amounts present in those harvested from banana leaves. Also, the amount of fat in $P$. pulmonarius was very infinitesimal compared to other proximate constituents regardless of the substrates used. The percentage fibre in $P$. pulmonarius in all three substrates ranged from $5.31 \%$ to $5.83 \%$. The highest percentage starch was observed in $P$. pulmonarius grown in cassava peels but ash in the same sample was the lowest as summarized in Figure 1.

The moisture in $P$. ostreatus grown in banana leaves was the highest and significantly different from $P$. ostreatus grown in both amended sawdust and cassava peels. The protein in $P$. ostreatus harvested from amended sawdust was significantly different from the amount obtained in the mushroom raised in banana leaves. The fat in $P$. ostreatus in cassava peels substrate was found to be highest. In banana leaves, the $P$. ostreatus harvested from the substrates had the highest fibre and starch contents. The ash in P. ostreatus harvested from all the substrates ranges from $7.99 \%$ to $11.21 \%$ as fully represented in Figure 2.

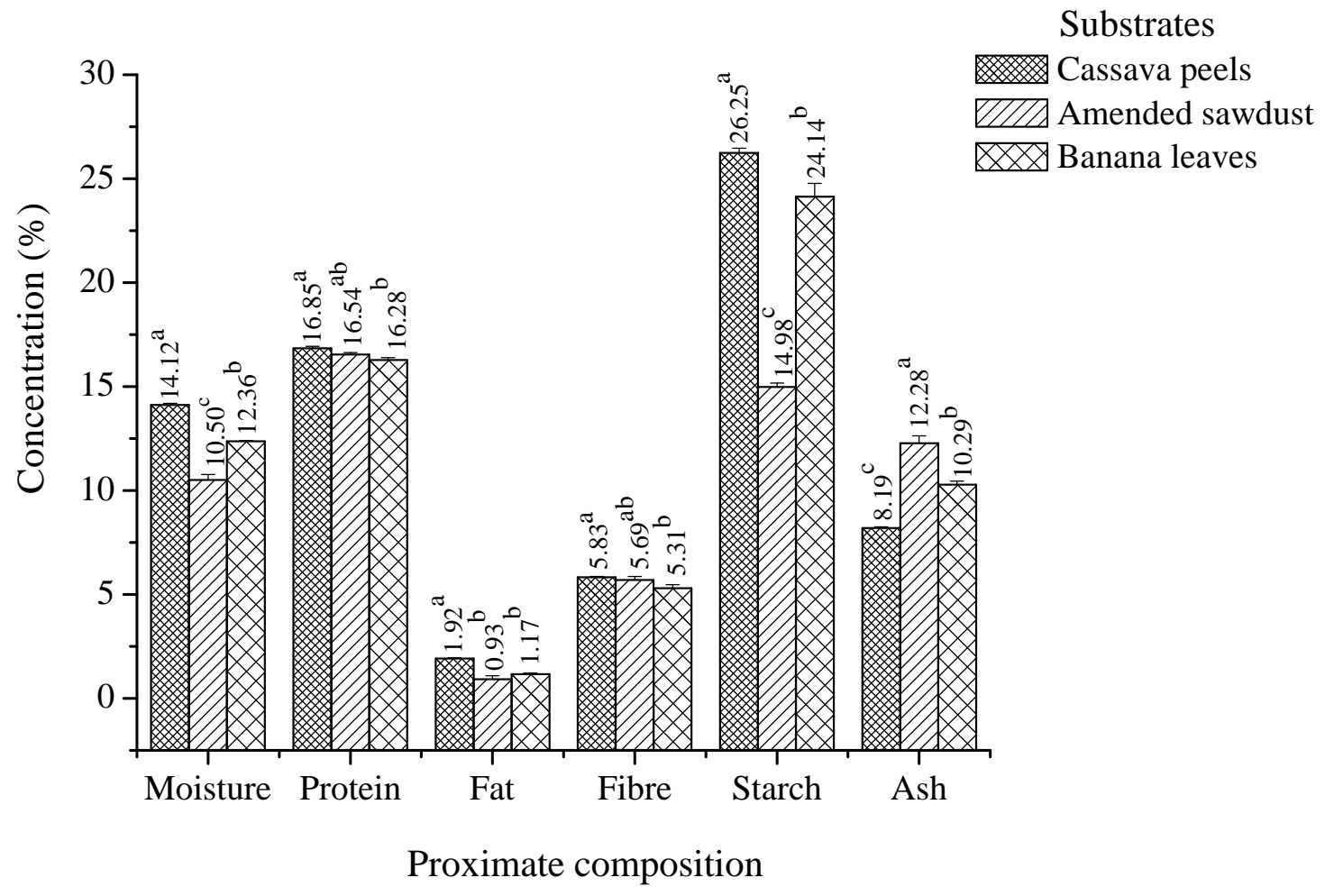

Figure 1: Proximate analysis of Pleurotus pulmonarius as influenced by substrates. 


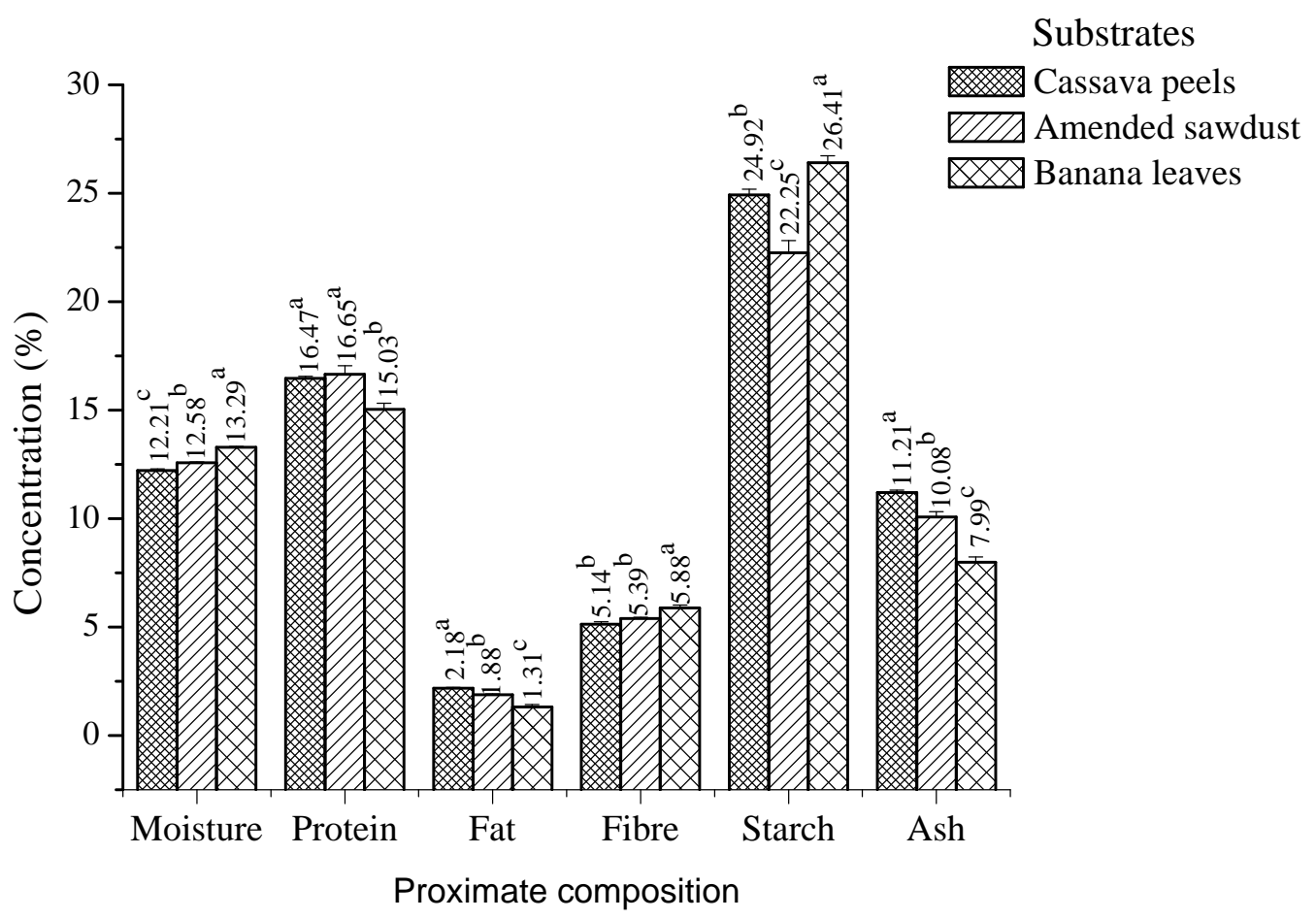

Figure 2: Proximate analysis of Pleurotus ostreatus as influenced by substrates.

\section{Effects of substrates on minerals in $P$. pulmonarius and $P$. ostreatus}

There were no significant differences in the $\mathrm{Zn}$ and $\mathrm{Mg}$ contentsin $P$. pulmonarius in all three substrates. The amounts $\mathrm{Mn}, \mathrm{Fe}$ and $\mathrm{Cu}$ contents in $P$. pulmonarius were significantly higher in the banana leaves substrates. $\mathrm{Mn}$ and $\mathrm{Cu}$ in $P$. pulmonariuscultivated in cassava peels and amended sawdust showed no significant difference. The level of $\mathrm{Ca}$ was found to be highest in the P. pulmonarius grown in cassava peels and the lowest level was recorded in those raised in banana leaves. $P$. pulmonarius in banana leaves hadthe lowest Se. The $\mathrm{K}$ in $P$. pulmonarius grown in cassava peels was the highest and was significantly different from that of banana leaves and amended sawdust. There was no significant difference in $\mathrm{K}$ contents of $P$. pulmonarius raised in both banana leaves and amended sawdust (Table 3).

As in $P$. pulmonarius, the $\mathrm{Zn}$ and $\mathrm{Mg}$ in $P$. ostreatus showed no significant difference from one another along the three substrates used.The $\mathrm{Mn}$ and $\mathrm{Fe}$ in the mushroom raised in sawdust werefound lowest. $P$. ostreatus grown in amended sawdust was the richest in $\mathrm{Ca}$ and was significantly different from the amounts obtained in thoseraised in other two substrates (Table 3). The highest amount of $\mathrm{K}$ was observed in $P$. ostreatus harvested from amended sawdust (Table 3).

\section{DISCUSSION}

Mushroom cultivation is a very profitable agribusiness as it can be raised in botanical wastes such as wheat straw, plant leaves and sawdust (Shah et al., 2004). Spawn running was fastest in banana leaves substrates but the highest pileus diameter and stipe height were observed in mushroom from amended sawdust which took about four weeks for complete spawn running. Differences in rate of spawn running may be attributed to the size of the grains (Pathmashini et al., 2008).The suitability of amended sawdust agreed with the work of Shah et al (2004) who both advocated the effectiveness of sawdust in mushroom cultivation. Wheat straw substrate is one of the best substrates in Pleurotus ostreatus cultivation (Kumari and Achal, 2008) and the produce has average pileus diameter that is higher than the one obtained from amended sawdust. 
Table 3: Mineral analysis of Pleurotus pulmonarius and Pleurotus ostreatus as influenced by substrates.

\begin{tabular}{|c|c|c|c|c|c|c|c|c|c|}
\hline & & $\mathrm{Zn}$ & $\mathrm{Mn}$ & $\mathrm{Fe}$ & $\begin{array}{c}\mathrm{Cu} \\
\mathrm{mg} / \mathrm{L}\end{array}$ & $\mathrm{Mg}$ & $\mathrm{Ca}$ & $\mathrm{Se}$ & $\mathrm{K}$ \\
\hline \multirow[t]{4}{*}{$\mathrm{Pp}$} & Banana leaves & $0.028 \pm 0.00^{\mathrm{a}}$ & $0.025 \pm 0.00^{\mathrm{a}}$ & $0.039 \pm 0.00^{\mathrm{a}}$ & $0.016 \pm 0.00^{\mathrm{a}}$ & $0.038 \pm 0.00^{\mathrm{a}}$ & $0.009 \pm 0.00^{\mathrm{c}}$ & $0.003 \pm 0.00^{\mathrm{c}}$ & $57.120 \pm 0.85^{b}$ \\
\hline & Cassava peels & $0.022 \pm 0.00^{\mathrm{a}}$ & $0.014 \pm 0.00^{\mathrm{b}}$ & $0.017 \pm 0.00^{\mathrm{c}}$ & $0.007 \pm 0.00^{\mathrm{bc}}$ & $0.055 \pm 0.00^{\mathrm{a}}$ & $0.041 \pm 0.00^{\mathrm{a}}$ & $0.007 \pm 0.00^{\mathrm{b}}$ & $63.941 \pm 1.48^{\mathrm{a}}$ \\
\hline & Amended sawdust & $0.022 \pm 0.00^{\mathrm{a}}$ & $0.012 \pm 0.00^{\mathrm{b}}$ & $0.026 \pm 0.00^{\mathrm{b}}$ & $0.004 \pm 0.00^{\mathrm{c}}$ & $0.049 \pm 0.01^{\mathrm{a}}$ & $0.036 \pm 0.01^{\mathrm{b}}$ & $0.009 \pm 0.00^{\mathrm{a}}$ & $58.826 \pm 0.00^{\mathrm{b}}$ \\
\hline & Mean & $0.024 \pm 0.00$ & $0.017 \pm 0.00$ & $0.027 \pm 0.00$ & $0.009 \pm 0.00$ & $0.047 \pm 0.00$ & $0.029 \pm 0.00$ & $0.006 \pm 0.00$ & $59.962 \pm 0.78$ \\
\hline \multirow[t]{4}{*}{ Po } & Banana leaves & $0.100 \pm 0.07^{\mathrm{a}}$ & $0.023 \pm 0.00^{\mathrm{a}}$ & $0.022 \pm 0.00^{\mathrm{a}}$ & $0.007 \pm 0.01^{\mathrm{ab}}$ & $0.032 \pm 0.01^{\mathrm{a}}$ & $0.036 \pm 0.00^{\mathrm{b}}$ & $0.001 \pm 0.00^{\mathrm{a}}$ & $59.678 \pm 0.85^{\mathrm{b}}$ \\
\hline & Cassava peels & $0.100 \pm 0.07^{\mathrm{a}}$ & $0.006 \pm 0.00^{\mathrm{b}}$ & $0.013 \pm 0.00^{\mathrm{b}}$ & $0.005 \pm 0.00^{\mathrm{b}}$ & $0.024 \pm 0.19^{\mathrm{a}}$ & $0.007 \pm 0.00^{\mathrm{c}}$ & $0.001 \pm 0.00^{\mathrm{a}}$ & $61.383 \pm 0.00^{\mathrm{b}}$ \\
\hline & Amended sawdust & $0.030 \pm 0.00^{\mathrm{a}}$ & $0.002 \pm 0.00^{\mathrm{b}}$ & $0.010 \pm 0.00^{\mathrm{b}}$ & $0.008 \pm 0.00^{\mathrm{a}}$ & $0.024 \pm 0.00^{\mathrm{a}}$ & $0.158 \pm 0.00^{\mathrm{a}}$ & $0.002 \pm 0.00^{\mathrm{a}}$ & $68.204 \pm 0.85^{\mathrm{a}}$ \\
\hline & Mean & $0.077 \pm 0.05$ & $0.010 \pm 0.00$ & $0.015 \pm 0.00$ & $0.007 \pm 0.00$ & $0.027 \pm 0.07$ & $0.067 \pm 0.00$ & $0.001 \pm 0.00$ & $63.088 \pm 0.57$ \\
\hline
\end{tabular}

Means followed by the same letter along the same column for each species of mushroom are not significantly different at $\mathrm{p} \leq 0.05$.

$\mathrm{Pp}=$ Pleurotus pulmonarius

$\mathrm{Zn}=\mathrm{Zinc}$

$\mathrm{Fe}=$ Iron

$\mathrm{Mg}=$ Magnesium

$\mathrm{Se}=$ Selenium
Po $=$ Pleurotus ostreatus

$\mathrm{Mn}=$ Manganese

$\mathrm{Cu}=$ Copper

$\mathrm{Ca}=$ Calcium

$\mathrm{K}=$ Potassium 
$P$. pulmonarius and $P$. ostreatus are very rich in carbohydrate notably starch. The bulk of mushroom fruiting bodies are made of carbohydrate (Wani et al, 2010). Chang et al. (1996) reported that the fruit bodies of mushrooms contained 40.3-50.7\% of carbohydrates. The quantity of fat in the species of Pleutorus was very low and was expected as mushrooms generally have low fat content (Wani et al, 2010). Oleic acid and linoleic acid are the major monounsaturated fatty acid and polyunsaturated fatty acid respectively in $P$. ostreatus (Deepalakshmi and Mirunalini, 2014). The percentage protein in the two Pleurotus species ranged from $15.03 \%$ to $16.85 \%$ but was below $27.30 \%$ to $25.35 \%$ as reported by Bhattacharjya et al. (2015). Chang (1980) reported that the crude protein in mushrooms rank below animal meats but well above most other foods. Protein content of Pleurotus depends on the composition of the substrates and species of mushrooms (Erjavec et al., 2012).It is reported that mushroom is generally becoming a reliable source of protein (Deepalakshmi and Mirunalini, 2014). Proteins of Pleurotus sp. mushroom have superior quality because some of the members of this genus contain complete proteins with a good distribution of essential amino acids and non-essential amino acids (Wang et al., 2001). Oyster mushrooms are rich in dietary fibres containing about 5-6\% and this quantity is within range as reported by Kalac (2009).

Minerals such as $\mathrm{Fe}, \mathrm{Cu}, \mathrm{Zn}, \mathrm{Mn}$ and $\mathrm{K}$ are essential metals since they play an important role in biological systems. Heavy metals such as Mn and $\mathrm{Cu}$ were present. Turkekul et al. (2004) reported that mushrooms have effective mechanisms to absorb heavy metals from their substrates. High $\mathrm{Zn}$ and $\mathrm{Fe}$ are contained in the Pleurotus especially in the fruiting body (Ijeh et al., 2009). Deficiency of $\mathrm{Zn}$ in diet may result to growth retardation, loss of appetite and impaired immune function (Prassad, 2004). Both $P$. pulmonarius and $P$. ostreatus can be taken as diet supplement. $\mathrm{Cu}$, like any other microelement are needed by the body in small quantity (Araya et al., 2006) and banana leaves substrate produce Pleurotus with highest amount of $\mathrm{Cu}$. Potassium was found to be highest in two species of Pleurotus harvested from all the substrates. This mineral element is very essential and plays a vital role in the body. Wang et al. (2001) reported that $\mathrm{K}$ is a co-factor of several enzymatic reactions and this is available in the mushroom in large quantities.

\section{CONCLUSION}

$P$. pulmonarius and $P$. ostreatus grew in the three substrates used in varying degree. However, banana leaves and amended sawdust substrates were found to be suitable for growth of the mushrooms. Potassium $(\mathrm{K})$ was found to be highest among all minerals tested in the two species. P. pulmonarius and $P$. ostreatus are rich in carbohydrate with low fat. Both species can be taken for dietary requirement as well as supplements to cater for deficient minerals in the body.

\section{REFERENCES}

Araya, M., Pizarro, F., Olivares, M., Arredondo, M. and Gonzalez, M. (2006). Understanding copper homeostasis in humans and copper effects on health. Biological Research, 39: 183-187.

Bahl, N. (1983). Medicinal value of edible fungi. Proceeding of the International Conference on Science and Cultivation Technology of Edible Fungi. Indian Mushroom Science II, Pp. 203-209.

Bhattacharjya, D. K. Ratan Kumar Paul, R. K., Miah, M. N. and Ahmed, K. U. (2015). Comparative study on nutritional composition of oyster mushroom (Pleurotus ostreatus Fr.) cultivated on different sawdust substrates. Bioresearch Communications, 1(2): 93-98

Chang, S. and Miles, P. G. (2004). Mushrooms: Cultivation, Nutritional value, medicinal effect and Environmental Impact Boca Raton. Florida: CR Press

Chang, S.T. (1980). Mushroom as human food. BioScience, 30: 339-401.

Chang, R. (1996). Functional properties of edible mushroom. Nutrition Reviews. 54: 91-93

Croan, S.C. (2004). Conversion of conifer wastes into edible and medicinal mushrooms. Forest Products Journal, 54: 68-76

Deepalakshmi, K. and Mirunalini, S. (2014). Pleurotus ostreatus: an oyster mushroom with nutritional and medicinal properties. Journal of Biochemical Technology, 5(2):718-726

Dlamini, B. E., Earnshaw, D. M. and Masarirambi, M. T. (2012). Growth and yield response of oyster mushroom (pleurotus ostreatus) grown on different locally available substrates. Current Research 4(5): 623-629

Erjavec, J., Kos, J., Ravnika, M., Dreo, T. and Sabotic, J. (2012) Proteins of higher fungi-from forest to application. Trends. Biotechnology, 30(5): 259-273

Ezeibekwe, I. O, Ogbonnaya, C. I, Unamba, C. I. N and Osuala, O. M (2009). Proximate analysis and mineral composition of edible mushrooms in 
parts of south eastern Nigeria. Report and Opinion, 1(4): 32-36

Gregori, A., Svagelj, M. and Pohleven, J. (2007). Cultivation techniques and medicinal properties of Pleurotus spp. Food Technology and Biotechnology, 45: 238-249

Girmay, Z., Gorems, W., Birhanu, G. and Zewdie, S. (2016). Growth and yield performance of Pleurotus ostreatus (Jacq. Fr.) Kumm (oyster mushroom) on different substrates. AMB Express, 6: 87

Gunde-Cimerman, N. (1999). Medicinal value of the genus Pleurotus (Fr.) P. Karst. (Agaricales S.I., Basidiomycetes). International Journal of Medicinal Mushrooms, 1: 69-80.

Ijeh, I., Okwujiako, I., Nwosu, P. C. and Nnodim, H. (2009). Phytochemical composition of Pleurotus tuber regium and effect of its dietary incorporation on body /organ weights and serum triacylglycerols in albino mice. Journal of Medicinal Plants Research, 3(11): 939-943

Kalac, P. (2009). Chemical composition and nutritional values of European species of wild growing mushrooms: A review. Food Chemistry, 113: $9-16$

Khan, K. Y., Khan, M. A., Niamat, R. Munir, M. Fazal, H. Mazari, P. Seema, N., Bashir, T., Kanwal, A. and Ahmed, S. N. (2011). Element content analysis of plants of genus Ficus using atomic absorption spectrometer. African Journal of Pharmacy and Pharmacology, 5(3): 317-321

Kumari, D. and Achal, V. (2008). Effect of different substrates on the production and non-enzymatic antioxidant activity of Pleurotus ostreatus (Oyster mushroom). Life Science Journal (3): 7376
Pathmashini, L., Arulnandhy, V. and Wijeratnam, R. S. W. (2008). Cultivation of oyster mushroom ( Pleurotus ostreatus) on sawdust.Ceylon Journal of Science,37 (2): 177-182

Prasad, A. S. (2004) Zinc deficiency: its characterization and treatment. Met Ions Biological Systems, 41: 103-137.

Rosado, F. R., Carbonero, E. R., Kemmelmeier, C., Tischer, C. A., Gorin, P. A. J., Iacomini, M. A. (2002). Partially 3-0-methylated $(1 \rightarrow 4)$ linked $\alpha$-d-galactan and $\alpha$-d-mannan from Pleurotus ostreatoroseus Sing. FEMS Microbiology Letter, 212: 261-265.

Sarker, N.C., Hossain M.M., Sultana, N, Mian, I.H., Karim, A.J.M.S. and Amin, S.M.R. (2007). Impect of different substrates on nutrient content of Pleurotus ostreatus (Jacquin ex Fr.) kummer. Bangladesh Journal of Mushroom. 1 (2), 35-38.

Shah, Z. A., Ashraf, M. and Ishtiaq, M. C. (2004). Comparative Study on Cultivation and Yield Performance of OysterMushroom (Pleurotus ostreatus) on Different Substrates (Wheat Straw, Leaves, Saw Dust). Pakistan Journal of Nutrition, 3 (3): 158-160.

Turkekul, I., Elmastas, M. and Tuzen, M. (2004), Determination of iron, copper, manganese, zinc, lead and cadmium in mushroom samples from Tokat, Turkey. Food Chemistry, 84, 389-392.

Wang, D., Sakoda, A. K. and Suzuki, M. (2001). Biological efficiency and nutritional values of Pleurotous ostreatus cultivated on spent beer grain. Bioresource Technology, 78:93-300

Wani, B. A., Bodha, R. H. and Wani, A. H. (2010). Nutritional and medicinal importance of mushrooms . Journal of Medicinal Plants Research, 4(24): 2598-2604 